\title{
ENZYMATIC HYDROLYSIS OF CHITIN BY MYROTHECIUM VERRUCARIA CHITINASE COMPLEX AND ITS UTILIZATION TO PRODUCE SCP ${ }^{a}$
}

\author{
PRANAV VYAS AND MUKUND DESHPANDE* \\ Biochemical Sciences Division, National Chemical Laboratory, \\ Pune 411008, India
}

(Received March 11, 1991)

The enzymatic hydrolysis of native and pretreated chitin by the culture filtrate of Myrothecium verrucaria NCIM 903 was studied. Also, factors which influence the enzymatic hydrolysis such as $\mathrm{pH}$, temperature, enzyme and substrate concentration and enzyme adsorption characteristics ( $n$-value) were studied. Chitin hydrolysate was also used as a substrate for Single Cell Protein (SCP) production using Saccharomyces cerevisiae NCIM 3052. With $M$. verrucaria chitinase complex, native and acid swollen chitin were hydrolyzed at $\mathrm{pH} 5.0$ and $40^{\circ} \mathrm{C}, 12.7 \%$ and $39.6 \%$ respectively. The $n$ values which is a measure of adsorption characteristics of an enzyme were 0.4 and 0.63 for native and acid swollen chitin, respectively. This indicates that the swelling of the ordered structure results in efficient hydrolysis. As the end-product of hydrolysis of chitin was mainly $\mathrm{N}$-acetyl-D-glucosamine, its further utilization as a substrate for SCP production was investigated. A biomass of $9.5 \mathrm{~g} / l$ with a growth yield of $0.27 \mathrm{~g} / \mathrm{g}$ of substrate utilized was obtained. The total protein and nucleic acid content of the biomass was $61 \%$ and $3.1 \%$, respectively.

Chitin, a biopolymer of $\beta$-( $1 \rightarrow 4)$-linked $N$-acetyl-D-glucosamine is broadly distributed in the biosphere. It constitutes a major component of the shells of crabs, krill, and shrimps (8). Conventional methods of sea food processing include chitin disposal by ocean dumping, incineration and land filling. However, factors such as cost of transportation and environmental pollution have prompted a search for

${ }^{a}$ NCL communication No. 5113.

* Address correspondence to: Dr. M. V. Deshpande, Biochemical Sciences Division, National Chemical Laboratory, Pune 411008, India.

Abbreviations: NAG, $N$-acetyl-D-glucosamine; GA, glucosamine; RS, reducing sugars; SCP, single cell protein; IU, international unit. 
alternative methods. Utilization of chitinous waste for single cell protein (SCP) production and its use in aquaculture feed is a widely acceptable alternative $(1,12$, 14).

Myrothecium verrucaria NCIM 903 is a potent producer of chitinolytic enzymes (18). Here we describe the results of studies on the enzymatic hydrolysis of chitin with $M$. verrucaria culture filtrate and further utilization of chitin hydrolysate for SCP production using Saccharomyces cerevisiae NCIM 3052.

\section{MATERIALS AND METHODS}

Organisms and cultivation conditions. Myrothecium verrucaria NCIM 903 was maintained on potato dextrose agar (2\% PDA) and Saccharomyces cerevisiae NCIM 3052 was maintained on malt extract-glucose-yeast extract-peptone agar (MGYP agar) slants.

For the enzyme production submerged fermentation by $M$. verrucaria was carried out in a medium containing $0.5 \%$ chitin as the sole carbon source. The seven-day-old culture filtrate $(\mathrm{pH} 7.8)$ was adjusted to $\mathrm{pH} 5.5$ with $2 \mathrm{M}$ citric acid and stored at $4{ }^{\circ} \mathrm{C}$ after adding sodium azide $(0.01 \%)$ as a preservative. For SCP experiments, the culture filtrate was harvested and stored as above under aseptic conditions replacing sodium azide with ampicillin $(0.05 \mathrm{mg} / \mathrm{ml})$. The chitinase and chitobiase activities of the preparation used in the hydrolysis experiments, determined at their optimum $\mathrm{pH}$ and temperature as described earlier (18), were (IU/ $\mathrm{ml}$ ): acid swollen chitin degrading activity, 2.0; endo-chitinase (EC 3.2.1.14) with ethylene glycol chitin, 0.44 and carboxymethyl chitin, 0.8; and chitobiase (EC 3.2.1.30) with $p$-nitrophenyl- $N$-acetyl- $\beta$-D-glucosaminide, 6.0.

Methods of analysis. The reducing sugars (RS), expressed as $N$-acetyl-Dglucosamine (NAG) were determined by the Nelson method (11), NAG by the method of Reissig et al. (13), and glucosamine (GA) by the method of Good and Bessman (2).

Paper chromatography (Whatman no. 1) was used to examine the sugars in hydrolysates. The solvent system used was 1-butanol-pyridine--water $(6: 4: 3, \mathrm{v} / \mathrm{v})$ (15). Reducing sugars were detected by spraying with a solution of $3 \% p$-anisidine in butanol (4). Prior to measuring sugar production, sample solutions were heated to precipitate soluble proteins and centrifuged to remove insoluble solids.

Percentage of enzymatic hydrolysis. The percentage of hydrolysis was determined under conditions similar to those described by Mandels et al. (7).

$$
\% \text { Hydrolysis }=\frac{\text { Amount of reducing sugars }}{\text { Amount of substrate }} \times \frac{203}{221} \times 100
$$

At the end of the hydrolysis $(48 \mathrm{~h})$, the degree of solubilization was determined by centrifuging the hydrolyzed solution. The residue was washed twice with distilled water and dried to constant weight in an oven at $60-65^{\circ} \mathrm{C}$. The percentage difference between this value and the initial solids content represent the degree of 
solubilization.

Preparation of substrate. Crab shell chitin (practical grade, Sigma Chemical Co. USA) was pretreated with $O$-phosphoric acid $(88 \%, 14 \mathrm{~N})$ as described previously (18), and with $\mathrm{HCl}(12 \mathrm{~N})$ as described by Shimahara and Takiguchi (16).

Enzymatic hydrolysis conditions. The substrate was hydrolyzed by adding 7 $\mathrm{ml}$ of culture filtrate (consisting of acid swollen chitin-degrading activity, $14 \mathrm{IU}$; endo-chitinase with ethylene glycol chitin, $3.08 \mathrm{IU}$ and with carboxymethyl chitin, 5.6 and chitobiase with $p$-nitrophenyl- $N$-acetyl- $\beta$-D-glucosaminide, $42 \mathrm{IU}$ ) to $1 \mathrm{~g}$ of substrate suspension made in $0.5 \mathrm{ml}$ of $1.0 \mathrm{M}$ acetate buffer $(\mathrm{pH} 5.0)$ then diluted to $10 \mathrm{~g}$ with distilled water. The reaction mixture was incubated for the desired period under shaking conditions at $40^{\circ} \mathrm{C}$ in a stoppered flask.

As acid-swollen chitin is the general substrate for chitinases in all the experiments, only acid swollen chitin has been involved in following degrading activity.

SCP production. The $S$. cerevisiae NCIM 3052 used for SCP was grown in a medium containing $(\mathrm{g} / \mathrm{l})$ : glucose, 10 ; yeast extract, 3.0; peptone, 5.0. The $\mathrm{pH}$ of the medium after autoclaving $\left(121^{\circ} \mathrm{C}\right.$ for $\left.20 \mathrm{~min}\right)$ was around 6.0. After $24 \mathrm{~h}$ of incubation at $28^{\circ} \mathrm{C}$ under shaking conditions $(200 \mathrm{rpm})$, harvested cells were washed twice with $0.9 \% \mathrm{KH}_{2} \mathrm{PO}_{4}$. Using $10 \%$ acid swollen chitin as a substrate, hydrolysis was carried out at $40^{\circ} \mathrm{C}$ for $48 \mathrm{~h}$ as mentioned above. The chitin hydrolysate (from $10 \mathrm{~g}$ substrate) obtained was supplemented with $0.67 \%$ yeast nitrogen base and inoculated with $1.2 \times 10^{9}$ cells of yeast. Cells harvested after 48 $\mathrm{h}$ of growth under shaking conditions at $28^{\circ} \mathrm{C}$ were studied for SCP parameters.

The biomass yield, protein and nucleic acid content and amino acid composition of $S$. cerevisiae 3052 were determined by the methods described by Levine and Cooney (6).

\section{RESULTS AND DISCUSSION}

\section{Pretreatment of chitin}

Practical grade chitin was pretreated with concentrated $O$-phosphoric acid (14 N) and concentrated hydrochloric acid $(12 \mathrm{~N})$ as described under Materials and Methods. The acid swollen chitin lost about $30 \%$ of its weight after $O$-phosphoric acid treatment. When hydrochloric acid was used, $35 \%$ of the weight was lost. The $O$-phosphoric acid-swollen chitin and native chitin were used for further studies.

The $\mathrm{pH}$ and temperature optima and the Arrhenius activation energies at the $\mathrm{pH}$ and temperature optima for the chitinase complex are shown in Table 1.

\section{Factors affecting hydrolysis of chitin}

The rate of release of reducing sugars from chitin (native as well as acid swollen) was examined as a function of $\mathrm{pH}$, temperature, enzyme concentration and substrate concentration, respectively.

The effect of $\mathrm{pH}$ on the hydrolysis of acid swollen chitin $(5 \%)$ at $40^{\circ} \mathrm{C}$ was 
Table 1. Optimum temperature, $\mathrm{pH}$ and activation energies for chitinases from $M$. verrucaria.

\begin{tabular}{cccc}
\hline Substrate & $\begin{array}{c}\text { Optimum } \\
\text { temperature } \\
\left({ }^{\circ} \mathrm{C}\right)\end{array}$ & $\begin{array}{c}\text { Optimum } \\
\mathrm{pH}\end{array}$ & $\begin{array}{c}\text { Activation } \\
\text { energy } \\
(\mathrm{kJ} / \mathrm{mol})\end{array}$ \\
\hline $\begin{array}{c}\text { Acid swollen } \\
\text { chitin } \\
\text { Carboxymethyl } \\
\text { chitin }\end{array}$ & 50 & 5.0 & 23.9 \\
$\begin{array}{c}\text { Ethyleneglycol } \\
\text { chitin }\end{array}$ & 50 & $4.5-5.5$ & 13.7 \\
Hydrolysis & 50 & 5.0 & 2.6 \\
\hline
\end{tabular}

studied. The maximum yield of reducing sugars $(21.2 \mathrm{mg} / \mathrm{ml})$ on hydrolysis was obtained at $\mathrm{pH} 5.0$ in $24 \mathrm{~h}$.

The variation in the hydrolysis of acid swollen chitin (5\%) with respect to temperature at $\mathrm{pH} 5.0$ was examined. A temperature of $40^{\circ} \mathrm{C}$ appeared to be most favorable for hydrolysis $(39.6 \%$ in $24 \mathrm{~h}$ ). The role of enzyme concentration on the

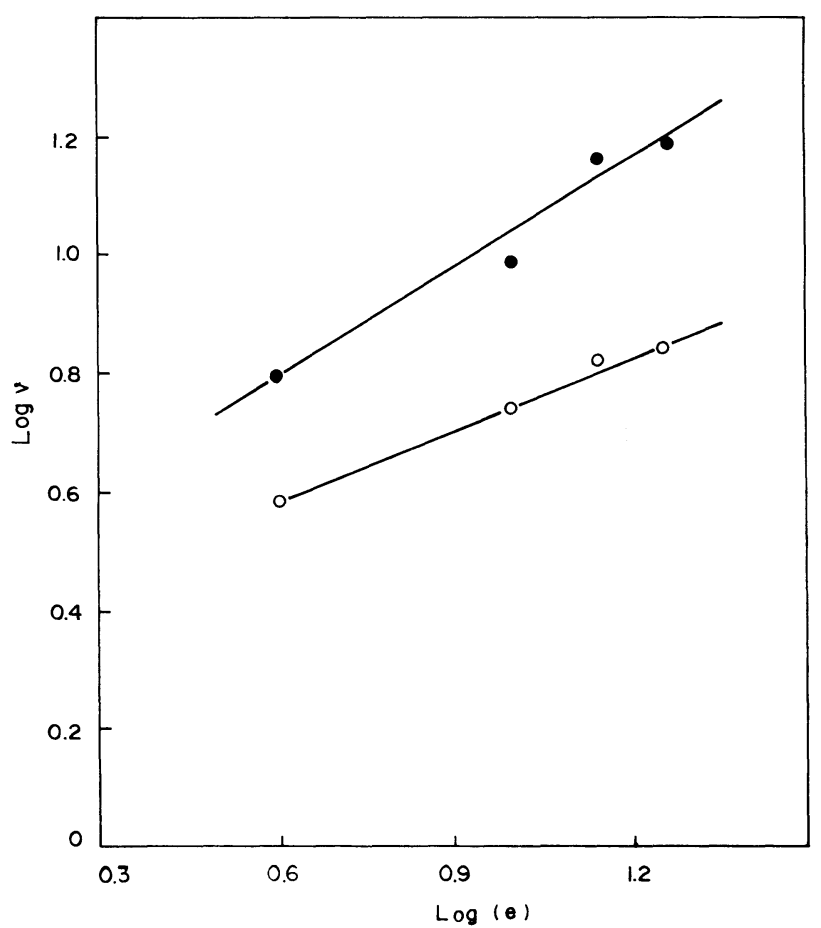

Fig. 1. Determination of $n$. Acid swollen and native chitin was hydrolyzed at $\mathrm{pH}$ $5.0,40^{\circ} \mathrm{C}, 0.5 \mathrm{~g}$ substrate $+0.5 \mathrm{ml}$ acetate buffer $(1 \mathrm{M}, \mathrm{pH} 5.0)+$ chitinase units $(4,10$, 14 or 18$)+0.1 \mathrm{ml}$ of sodium azide $(0.1 \%)+$ water to $10 \mathrm{~g}$. $\log \mathrm{v}$ : \% hydrolysis, $\log \mathrm{e}$ : chitinase units. Reaction time, 4 h. $\bigcirc$, native chitin; $\bullet$, acid swollen chitin. 
extent of hydrolysis and yield of reducing sugars was studied. The results obtained using $10 \%$ native chitin showed that the extent of hydrolysis $(5.2-16.9 \%$ in $48 \mathrm{~h}$ ) increased with the increasing concentration of the enzyme (4-18 IU in $10 \mathrm{~g}$ reaction mixture). In the case of acid swollen chitin, there was no increase in the release of reducing sugars (i.e. not more than $39 \mathrm{mg} / \mathrm{ml}$ in $48 \mathrm{~h}$ ) when the concentration of the enzyme was increased above 14 IU. With native chitin the hydrolysis increased $25-$ $35 \%$. The extent of hydrolysis of the chitins was not in proportion to the increase in enzyme concentration. And there was faster rate of hydrolysis during the first 4 $h$ followed by a decrease in the rate.

Regarding the effect of enzyme concentration on the rate of hydrolysis (Fig. 1), our data confirmed the equation developed by McLaren (9) describing the hydrolytic rate of enzymatic reaction in a heterogeneous system, e.g. soluble enzyme and insoluble substrate. The rate constant for the enzymatic reaction, $n$, which describes the adsorption characteristics of the enzyme was higher (0.63) for acid-swollen chitin than for native chitin (0.4).

With $15 \%$ acid-swollen chitin, the reducing sugars produced in $48 \mathrm{~h}$ was $4.5 \%$

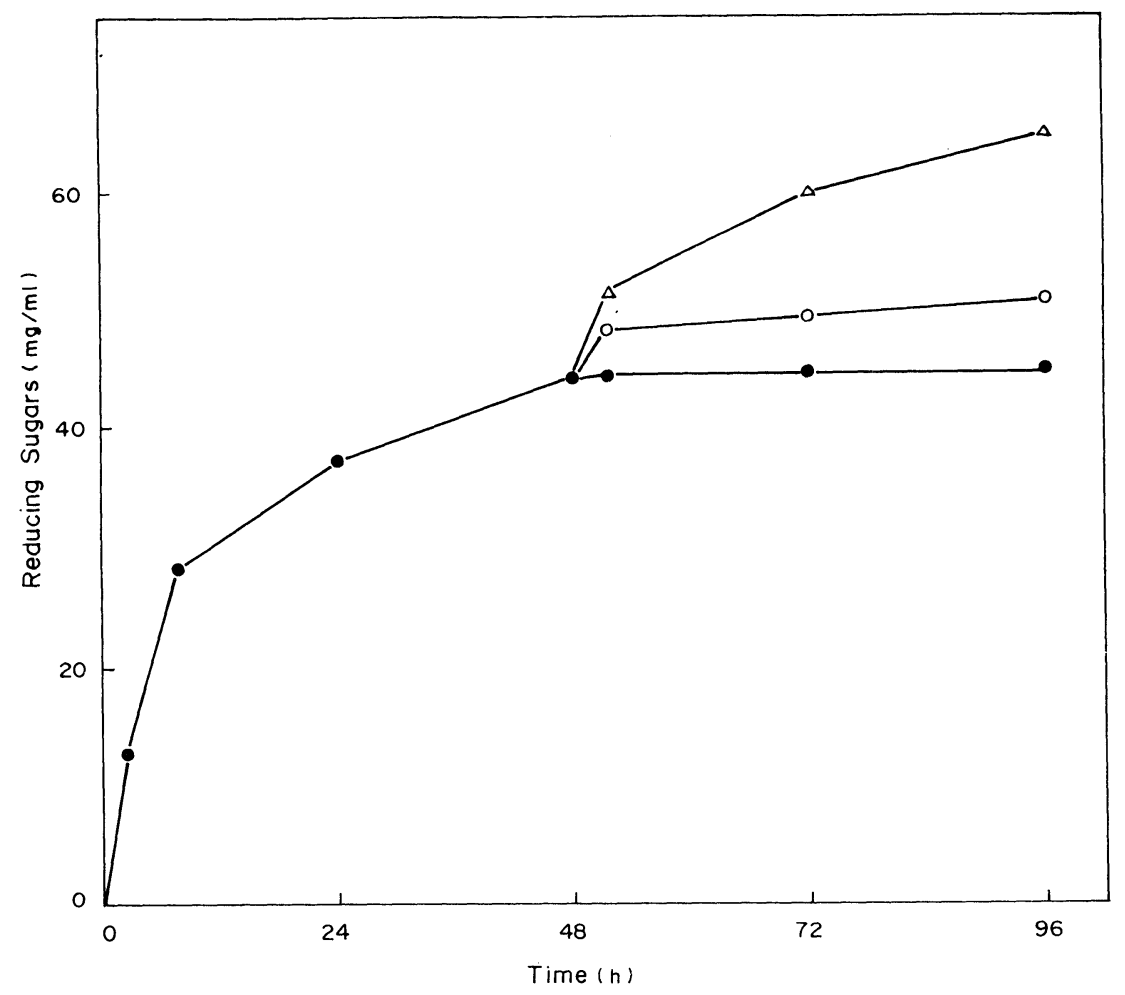

Fig. 2. Effect of adding more enzyme or substrate to acid swollen chitin after 48$\mathrm{h}$ incubation. $1.5 \mathrm{~g}$ acid-swollen chitin $+0.5 \mathrm{ml}$ acetate buffer $(1 \mathrm{M}, \mathrm{pH} 5.0)+14$ chitinase units $+0.1 \mathrm{ml}$ of sodium azide $(0.1 \%)+$ water to $10 \mathrm{~g}$, incubated at $40^{\circ} \mathrm{C}$.

-: control, $: 10$ chitinase units added after $48 \mathrm{~h}, \triangle: 0.5 \mathrm{~g}$ substrate added after $48 \mathrm{~h}$. 
Table 2. Hydrolysis of chitin by $M$. verrucaria culture filtrate at different substrate concentrations.

\begin{tabular}{|c|c|c|c|c|c|c|c|c|c|}
\hline \multirow[b]{2}{*}{$\begin{array}{c}\text { Substrate } \\
(\%)\end{array}$} & \multicolumn{4}{|c|}{ Reducing sugars } & \multicolumn{4}{|c|}{ Hydrolysis } & \multirow[b]{2}{*}{$\begin{array}{l}\text { DS } \\
(\%)\end{array}$} \\
\hline & $1 \mathrm{~h}$ & $\begin{array}{l}4 \mathrm{~h} \\
(\mathrm{mg}\end{array}$ & $\begin{array}{l}24 \mathrm{~h} \\
\mathrm{nl})\end{array}$ & $48 \mathrm{~h}$ & $1 \mathrm{~h}$ & & $24 \mathrm{~h}$ & $48 \mathrm{~h}$ & \\
\hline \multicolumn{10}{|l|}{ Native chitin } \\
\hline 5 & 3.0 & 6.9 & 6.9 & 6.9 & 5.5 & 12.7 & 12.7 & 12.7 & 13.2 \\
\hline 10 & 6.4 & 10.0 & 13.4 & 13.9 & 5.9 & 9.2 & 12.3 & 12.8 & \\
\hline 15 & 7.2 & 10.1 & 14.3 & 18.6 & 4.4 & 6.2 & 8.7 & 11.4 & \\
\hline 20 & 7.9 & 10.4 & 20.8 & 20.8 & 3.6 & 4.8 & 9.6 & 9.6 & \\
\hline \multicolumn{10}{|c|}{ Acid swollen chitin } \\
\hline 5 & 14.6 & 20.1 & 21.5 & 21.5 & 26.3 & 37.0 & 39.6 & 39.6 & 40.2 \\
\hline 10 & 15.6 & 24.6 & 31.0 & 39.0 & 14.4 & 22.6 & 28.5 & 36.0 & \\
\hline 15 & 13.6 & 28.8 & 46.0 & 54.3 & 8.3 & 17.6 & 28.1 & 33.1 & \\
\hline 20 & 13.5 & 29.4 & 49.3 & 63.1 & 6.2 & 13.5 & 22.7 & 29.0 & \\
\hline
\end{tabular}

One, two, three or four grams of chitin $+1.0 \mathrm{ml}$ of $1 \mathrm{M}$ acetate buffer, $\mathrm{pH} 5.0,+0.2 \mathrm{ml}$ of sodium azide $(0.1 \%)+28$ chitinase units + water to $20 \mathrm{~g}$.

DS: degree of solubilization measured as described under MATERIALS AND METHODS.

(Fig. 2). When more substrate (5.0\%) was added at the end of $48 \mathrm{~h}$, the reducing sugars increased during a further 48 -h incubation. The increment of the reducing sugars corresponded to $44 \%$ of the added substrate. Thus, the increase is due to the replenishment of the substrate. However, there was $20 \%$ loss of enzyme activity after $48 \mathrm{~h}$ and it was further increased up to $60 \%$ at the end of $96 \mathrm{~h}$ under hydrolysis conditions in the control. There was an increase of $14.6 \%$ in reducing sugars when $10 \mathrm{IU}$ of an enzyme was added after $48 \mathrm{~h}$. The control with no addition of either substrate or enzyme did not appreciably increase the reducing sugars during further incubation.

The effect of substrate concentration on reducing sugars released and the percentage of hydrolysis is shown in Table 2. The amount of reducing sugars released increased with the increase in the concentration of substrate. But the extent of hydrolysis per gram of the substrate hydrolyzed is decreased. The reducing sugars produced from the native chitin under the substrate concentrations studied (5-20\%) was much less than that produced from the pretreated chitin. This is in conformity with the higher $n$ for acid-swollen chitin than for native chitin.

The optimum substrate concentration, according to Toyama and Ogawa (17), taking into account the conditions which give high sugar solutions and also a high degree of substrate utilization, appears to be around $9 \%$ for both acid-swollen and native chitin (Fig. 3). Analysis of the hydrolysate from acid swollen and native chitin at 5\% substrate concentration showed the reducing sugars (as NAG equivalent) to be $21.6 \mathrm{mg} / \mathrm{ml}$ and $6.9 \mathrm{mg} / \mathrm{ml}$, respectively in $24 \mathrm{~h}$.

\section{Product of hydrolysis}

Chitin upon complete hydrolysis gives NAG as the sole end product. How- 


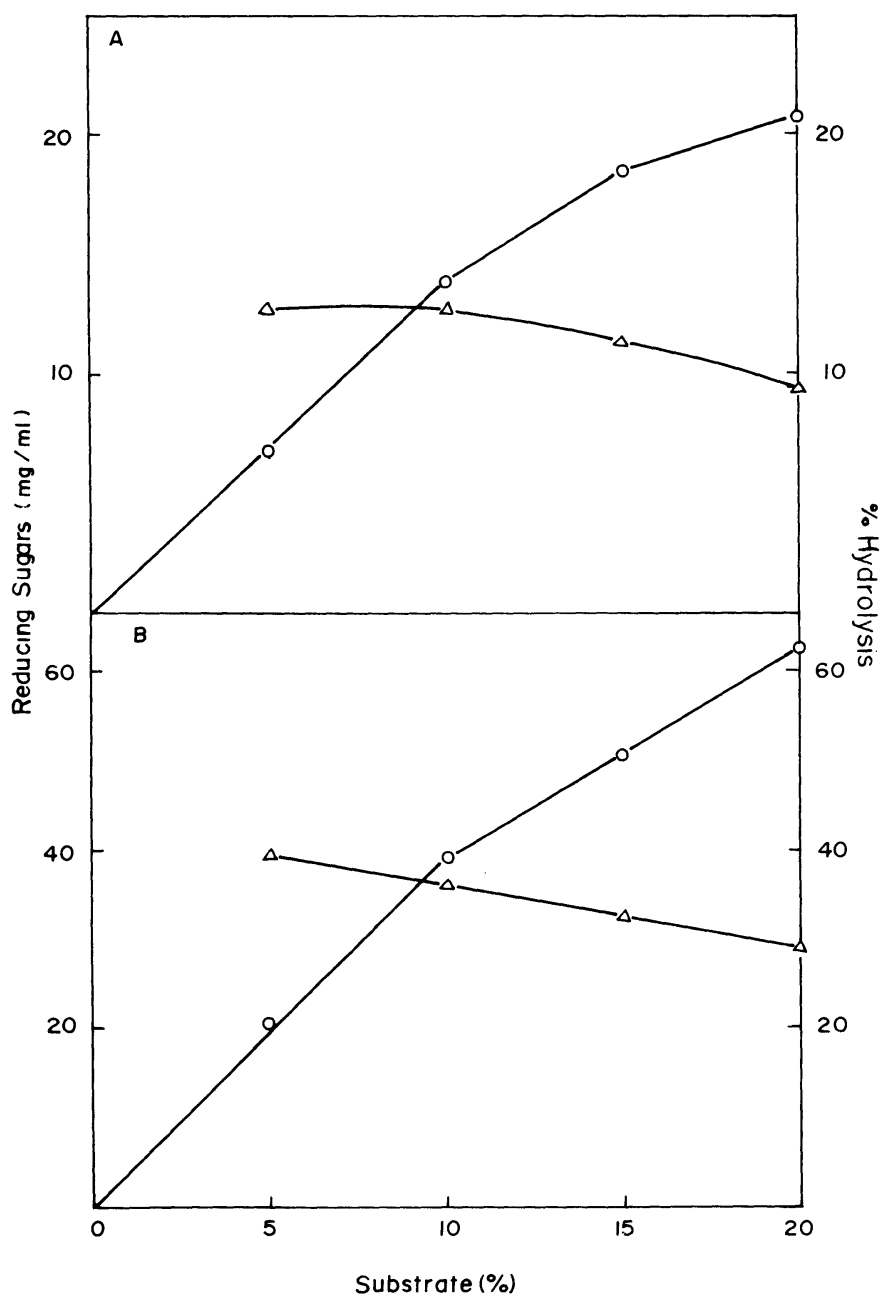

Fig. 3. Effect of substrate concentration on enzymatic hydrolysis. One, two, three or four grams of substrate $+1.0 \mathrm{ml} 1 \mathrm{M}$ acetate buffer, $\mathrm{pH} 5.0,+0.2 \mathrm{ml}$ sodium azide $(0.1 \%)+28$ chitinase units + water to $20 \mathrm{~g}$. $\bigcirc$, reducing sugars; $\triangle, \%$ hydrolysis. Reaction time, $48 \mathrm{~h}$. A: native chitin, B: acid swollen chitin.

ever, deacetylation of chitin, either enzymic or chemical, may lead to the formation of GA. Hackman and Goldberg (3) have shown that chitins from different sources differ significantly in the ratio of GA to NAG in the chitin molecule. Therefore we estimated the concentration of NAG and GA in the chitin hydrolysate.

The concentration of NAG, GA and total reducing sugars produced by $M$. verrucaria chitinase during the hydrolysis of acid-swollen and native chitin up to 48 $h$ is shown in Table 3. Paper chromatogrphy showed only NAG in the initial period of hydrolysis $(4 \mathrm{~h})$, however, GA appeared in $24-\mathrm{h}$ and $48-\mathrm{h}$ samples. The 
Table 3. Formation of sugars during enzymatic hydrolysis of chitin by $M$. verrucaria culture filtrate.

\begin{tabular}{cccc}
\hline $\begin{array}{c}\text { Sample } \\
(\mathrm{h})\end{array}$ & $\mathrm{RS}$ & $\mathrm{NAG}$ & GA \\
\cline { 2 - 3 } & & $(\mathrm{mg} / \mathrm{ml})$ & \\
\hline Native chitin & 7.5 & 7.5 & ND \\
1 & 10 & 9.9 & ND \\
4 & 19.6 & 19.5 & ND \\
24 & 19.6 & 19.5 & \\
48 & & & 0.3 \\
Acid swollen chitin & 21.5 & 21.2 & 1.6 \\
1 & 32.4 & 30.0 & 3.8 \\
4 & 55.0 & 52.0 & 3.8 \\
24 & 65.2 & 61.0 & \\
\hline
\end{tabular}

Hydrolysis was carried out with $20 \%$ substrate, pH $5.0,40 \mathrm{C}$.

ND: not detected.

predominance of NAG as the major end product of hydrolysis may be attributed to the high chitobiase activity. As the end product of chitin hydrolysis was mainly NAG, its utilization as a substrate for either biomass or SCP production was considered to be of great significance.

\section{Selection of yeast for SCP}

During screening for SCP in a number of yeast strains on agar medium containing chitin hydrolysate with a yeast nitrogen source, S. cerevisiae NCIM 3052 was found to be the best one. Further studies on SCP production have been carried out using NCIM 3052 strain.

Acid swollen chitin was hydrolyzed at $40^{\circ} \mathrm{C}$ for $48 \mathrm{~h}$ at $\mathrm{pH} 5.0$ using $\boldsymbol{M}$. verrucaria chitinase. The chitin hydrolysate was supplemented with yeast nitrogen base to favor the growth of $S$. cerevisiae. The criteria used for the evaluation of SCP production include growth yield, total protein and nucleic acid contents. Serratia marcescens was reported to produce high chitinolytic activity (10). Using the culture filtrate of $S$. marcescens Revah-Moiseev and Carrod (14) have carried out saccharification of shell fish waste chitin, the hydrolysate thus obtained was utilized for SCP production using Pichia kudriavzevii. Our results show that $S$. cerevisiae is a better substitute than $P$. kudriavzevii as its protein content is higher (61\% as compared to $45 \%)$ and the nucleic acid content is lower $(3.1 \%$ as compared to $8-11 \%$ ), which are the criteria preferred for SCP.

The amino acids of the total proteins was analyzed. The relative amounts of amino acid obtained is similar to that reported for typical yeast (5).

The results of the study indicate that $M$. verrucaria chitinase complex hydrolyzes chitin to NAG because of high chitobiase activity. The culture filtrate can be used for the enzymatic hydrolysis of crab shell chitin and S. cerevisiae is a good yeast to use for SCP production. 
Mr. Pranav Vyas is grateful to the Council of Scientific and Industrial Research, New Delhi for the award of a Senior Research Fellowship.

\section{REFERENCES}

1) Deshpande, M. V., Enzymatic degradation of chitin and its biological applications. J. Sci. Ind. Res., 45, 273-281 (1986).

2) Good, T. A. and Bessman, S. P., Determination of glucosamine and galactosamine using borate buffers for modification of Elson-Morgan and Morgan-Elson reactions. Anal. Biochem., 9, 253-262 (1964).

3) Hackman, R. H. and Goldberg, M., Studies on chitin. VI. The nature of $\alpha$-and $\beta$-chitins. Aus. $J$. Biol. Sci., 18, 935-946 (1965).

4) Hough, L., Jones, J. K. K., and Wadman, W. H., Quantitative analysis of mixtures of sugars by the method of partition chromatography. Studies on chitin. Part. VI. Improved methods for the separation of sugars and their methylated derivatives on the paper chromatogram. J. Chem. Soc., 229, 1702-1706 (1950).

5) Kihlberg, R., The microbe as a source of food. Ann. Rev. Microbiol., 26, 427-466 (1972).

6) Levine, D. W. and Cooney, C. L., Isolation and characterisation of thermotolerant methanol utilizing yeast. Appl. Microbiol., 26, 982-990 (1973).

7) Mandels, M., Hontz, L., and Nystrom, J., Enzymatic hydrolysis of waste cellulose. Biotechnol. Bioeng., 16, 1471-1493 (1974).

8) Mauldin, A. F. and Szabo, A. J., Shrimp canning waste treatment study. U. S. Environ. Prot. Agency, publication no. EPA-660/2 74-061 (1974) (CA: 1976, 84, 95224).

9) McLaren, A. D., Enzyme reactions in structurally related systems. IV. The digestion of insoluble substrates by hydrolytic enzymes. Enzymologia, 26, 237-246 (1963).

10) Monreal, J. and Reese, E. T., Chitinase of Serratia marcescens. Can. J. Microbiol., 15, 689-695 (1969).

11) Nelson, N., A photometric adaptation of the Somogyi method for the determination of glucose. J. Biol. Chem., 153, 375-380 (1944).

12) Ramond, T. A. and Carrod, P. A., Effect of reaction conditions on hydrolysis of chitin by Serratia marcescens QMB 1466 chitinase. J. Food Sci., 46, 646-647 (1981).

13) Reissig, J. L., Strominger, J. L. and Leloir, L. F., A modified colorimetric method for the estimation of $N$-acetyl amino sugars. J. Biol. Chem., 217, 959-966 (1955).

14) Revah-Moiseev, S. and Carrod, P. A., Conversion of the enzymatic hydrolysate of shellfish waste chitin to single cell protein. Biotechnol. Bioeng., 23, 1067-1078 (1981).

15) Sherma, J. and Zweig, G., Carbohydrates. In Paper Chromatography and Electrophoresis, Vol. 2, ed. by J. Sherma and Zweig, G., Acadamic Press, New York and London (1971), p. 152-169.

16) Shimahara, A. K. and Takiguchi, Y., Preparation of crustacean chitin. Methods in Enzymol., 161, 417-426 (1988).

17) Toyama, N. and Ogawa, K., Sugar production from agricultural woody wastes by saccharification with T. viridae cellulase. Biotechnol. Bioeng. Symp., 5, 225-244 (1975).

18) Vyas, P. R. and Deshpande, M. V., Chitinase production by Myrothecium verrucaria and its significance for fungal mycelia degradation. J. Gen. Appl. Microbiol., 35, 343-350 (1989). 